\title{
A prospective observational study of drug prescription pattern of antibiotics in diabetic foot ulcer in tertiary care teaching hospital
}

\author{
Kamalavarshini Paramasivamsasanger ${ }^{1 *}$, Prema Mariappan ${ }^{2}$, Dhivya Govindasamy ${ }^{1}$, \\ Padmavathi Karunakaran', Rajalakshmi Ramesh ${ }^{1}$
}

\author{
${ }^{1}$ Department of Pharmacy, Annamalai University, Chidambaram, Tamil Nadu, India \\ ${ }^{2}$ Department of Surgery, Rajah Muthiah Medical College Hospital, Annamalai University, Chidambaram, Tamil Nadu, \\ India
}

Received: 06 May 2020

Revised: 11 June 2020

Accepted: 12 June 2020

\section{*Correspondence:}

Dr. Kamalavarshini Paramasivamsasanger,

Email: psukamali@gmail.com

Copyright: (c) the author(s), publisher and licensee Medip Academy. This is an open-access article distributed under the terms of the Creative Commons Attribution Non-Commercial License, which permits unrestricted non-commercial use, distribution, and reproduction in any medium, provided the original work is properly cited.

\begin{abstract}
Background: Our aim was to study a prescribing pattern of antibiotics used in diabetic foot ulcer (DFU).

Methods: 50 patients were selected by inclusion and exclusion criteria basis. It was a prospective observational study conducted in Department of Surgery, Rajah Muthiah Medical College Hospital (RMMCH), Annamalai University.

Results: This study reveals that male patients $60 \%$ are more prone to develop diabetic foot ulcer than the female patients $40 \%$. Patients of 50 to 60 age group $32 \%$ has higher prevalence of DFU. The most commonly prescribed antibiotics are metronidazole $48 \%$ and cefotaxime $48 \%$ followed by piperacillin and tazobactam combination $30 \%$, ciprofloxacin $20 \%$, linezolid $18 \%$, amoxicillin and clavulanic acid combination $12 \%$, cefixime $6 \%$, clindamycin $4 \%$, amikacin $4 \%$, faropenam $4 \%$, ceftriaxone $2 \%$, amoxicillin $2 \%$, gentamicin $2 \%$, cefoperazone sodium and sulbactam combination $2 \%$.

Conclusions: Lack of antibiotic sensitivity test leads to growth of organism, wrong antibiotic selection and irrational use of antibiotics. And also observed patient developed resistance to linezolid antibiotic when used as a first choice of drug to treat diabetic foot infection including methicillin-resistant Staphylococcus aureus (MRSA) infected patients.
\end{abstract}

Keywords: DFU, Antibiotic sensitivity, Prescription pattern, MRSA

\section{INTRODUCTION}

Diabetic foot ulcer, major problem that can impair the quality of life, require prolong hospitalization and entails high cost to the patient. Diabetic foot disease affects about $5 \%$ of diabetic patients foot disease affects about $15 \%$ of diabetic patients. ${ }^{1,2}$ It is estimated that $19-34 \%$ of patients with diabetes are likely to be affected with a diabetic foot ulcer in their life times and the International Diabetes Federation reports that 9.1-26.1 million people will develop DFUs annually. ${ }^{3,4}$ Infection is a common and serious complication of diabetic foot wounds. Infection leads to formation of microthrombi, causing further ischemia, necrosis, and progressive gangrene. Massive infection is the most common factor leading to amputation. Local trauma and/or pressure (often in association with lack of sensation because of neuropathy), in addition to microvascular disease, may result in various diabetic foot infections that run the spectrum from simple, superficial cellulitis to acute and chronic osteomyelitis and deep-skin and soft-tissue infections. ${ }^{5}$ DFUs are relatively common. Once the protective layer of a skin is broken, deep tissues are exposed to a bacterial infection that progress rapidly. DFUs frequently requires amputation of the lower limbs and is the predominant factor. ${ }^{6,7}$ The incidence of foot 
ulcers ranges from 8-11 percent in India. ${ }^{8}$ The clinician seeing a patient with a diabetic foot ulcer always assess for the presence of and infection and if, present classify the infection's severity. ${ }^{9}$ The clinical diagnosis of foot infection is based on the presence of purulent discharge from an ulcer or the classic signs of inflammation i.e., erythema, pain, tenderness, warmth or induration. ${ }^{10}$ If the ulcers appear infected tissue sample testing in a microbiology laboratory may be helpful in identifying the types of bacteria causing the infection and choosing and appropriate antibiotic. An infected ulcer is usually treated with an oral antibiotic for 1 to 2 weeks. If the bone has infected only for a short time or if removing the dead bone is not possible, a patient may be prescribed a long course of intravenous antibiotics. ${ }^{11}$ Most moderate to severe soft tissue diabetic foot infections are polymicrobial (i.e., due to gram-positive, gram-negative, aerobic, and anaerobic pathogens). Empiric antibiotic therapy should include broad-spectrum antibiotics capable of covering the most common pathogens found in diabetic infections. ${ }^{12}$ Establishing presence of infection is an important component of ulcer care. Not all ulcers are infected and given increasing antibiotic resistance and risk of antibiotics related adverse events including diarrhoea and Clostridium difficile infection, the goal for antibiotic use in foot ulceration is to treat and active infective process, aiming to tailor therapy to the appropriate pathogen(s) ${ }^{13}$. It is mandatory upon all doctors to use medicines rationally, particularly in respect of antibiotics. The "Rule of Right" - right medicine in the right manner (dose, route, frequency, and duration of administration) in the right patient at right cost - must be followed while using antibiotics. Unfortunately, irrational use of antibiotics is rampant and as common as the infectious diseases are. Irrational use of antimicrobials in clinical practice leads to several problems such as, failure of treatment, adverse drug reactions, superinfections, prolongation of therapy, development of antimicrobial resistance and increase in cost of therapy. Causes of irrational use of antimicrobials include, inadequate medical training, non-availability of diagnostic facilities, large-scale availability and use of irrational, fixed dose drug combinations of antimicrobials, and ignoring the basic principles of selection and use of antimicrobials. ${ }^{14}$ Prescription pattern monitoring studies (PPMS) are drug utilization studies with the main focus on prescribing, dispensing and administering of drugs. They promote appropriate use of monitored drugs and reduction of abuse or misuse of monitored drugs. ${ }^{15}$

The aim of PPMS is to facilitate the rational use of drugs in a population. Irrational use of medicines is a major problem worldwide. World Health Organisation (WHO) estimates that more than half of all medicines are prescribed, dispensed or sold inappropriately, and the half of all patients fail to take them correctly. The rational use of medicines (RUM) is defined as patients receive medications appropriate to their clinical needs, in doses that meet their own individual requirements, for an adequate period of time, and at the lowest cost to them and their community. ${ }^{16,17}$

\section{Objectives}

The present study was conducted with an aim to study a prescribing pattern of antibiotics used in diabetic foot ulcer (DFU).

\section{METHODS}

Prospective observational study. Study period and duration from October to December 2019 and 3 months, sample size 50. The study was done Department of Surgery, Rajah Muthiah Medical College Hospital (RMMCH), Annamalai University.

\section{Inclusion criteria}

Inclusion criteria were patients with history of diabetes, patients of both genders, patients more than 30 of age and less than 80 of age, and prescription with antibiotics.

\section{Exclusion criteria}

Exclusion criteria were patients with comorbidities such as hypertension, coronary artery disease (CAD), history of diabetes mellitus type 1 , pregnant and mentally ill patients, and over the count medications (OTC).

Patients details collected through patient data collection form. Patient data collection of form consists of details such as patient gender, age, in-patient number, date of admission and date of discharge, chief complains, history of present illness, past history, laboratory investigations, diagnosis, medications.

Antibiotic culture sensitivity test includes sample type, organism isolated, organism growth and antibiotic susceptibility, antibiotic resistance of drugs. Further information of patient underwent surgery methods.

Risk factors are useful to consider which patient are in risk category. Grading score calculated by using Saint Elian wound score system and infectious disease society of America. ${ }^{22}$

\section{RESULTS}

On the basis of inclusion and exclusion criteria 50 patients were included in this study. Male patients are more affected with DFU than female patients (Table 1). Age of 50 to 60 patients are more prevalence of DFU (Table 2).

Risk factors classified into 3 categories and they are normal plantar sensation $18 \%$, loss of plantar sensation $14 \%$, loss of plantar sensation with either high pressure or poor circulation $4 \%$ and history of amputation or ulceration or neuropathic fracture $68 \%$ (Table 3 ). 
According to grading Saint Elian wound score system and infectious disease society of America, infection classified as mild $16 \%$, moderate $72 \%$, severe $12 \%$ (Table 4).

Surgical procedures used in DFU are wound debridement $56 \%$, grafting $8 \%$, amputation $30 \%$ and osteotomy $6 \%$ (Figure 1).

The most commonly prescribed antibiotics are cefotaxime $48 \%$ and metronidazole $48 \%$ and the combination used are piperacillin with tazobactam $30 \%$, amoxicillin with clavulanic acid $10 \%$, cefoperazone sodium with sulbactam $2 \%$ and others are ciprofloxacin $20 \%$, cefixime $6 \%$, ceftriaxone $2 \%$, clindamycin $4 \%$, linezolid 18\%, amoxicillin 2\%, gentamycin $2 \%$, faropenam 4\%, amikacin 4\% (Table 5).

Only $6 \%$ patients are not infected with bacteria. Organisms isolated from the patient samples are gram positive cocci $28 \%$ and gram-negative bacilli $24 \%$ and $2 \%$ of both gram-positive cocci with gram negative bacilli (Table 6).

Table: 1 Gender wise distribution.

\begin{tabular}{|lll|}
\hline Gender & $\begin{array}{l}\text { Number of } \\
\text { patients }\end{array}$ & $\begin{array}{l}\text { Percentage of } \\
\text { patients (\%) }\end{array}$ \\
\hline Male & 30 & 60 \\
\hline Female & 20 & 40 \\
\hline
\end{tabular}

Table 2: Age wise distribution.

\begin{tabular}{|lll|}
\hline $\begin{array}{l}\text { Age } \\
\text { (in years) }\end{array}$ & $\begin{array}{l}\text { Number of } \\
\text { patients }\end{array}$ & $\begin{array}{l}\text { Percentage of } \\
\text { patients }(\%)\end{array}$ \\
\hline $\mathbf{3 0 - 4 0}$ & 4 & 8 \\
\hline $\mathbf{4 0 - 5 0}$ & 6 & 12 \\
\hline $\mathbf{5 0 - 6 0}$ & 16 & 32 \\
\hline $\mathbf{6 0 - 7 0}$ & 9 & 18 \\
\hline $\mathbf{7 0 - 8 0}$ & 6 & 12 \\
\hline
\end{tabular}

Table 3: Risk factors.

\begin{tabular}{|lll|}
\hline Risk category & $\begin{array}{l}\text { Number } \\
\text { of patients }\end{array}$ & Patients (\%) \\
\hline $\begin{array}{l}\text { Normal plantar } \\
\text { sensation }\end{array}$ & 9 & 18 \\
\hline $\begin{array}{l}\text { Loss of plantar } \\
\text { sensation }\end{array}$ & 7 & 14 \\
\hline $\begin{array}{l}\text { Loss of plantar } \\
\text { sensation with either } \\
\text { high pressure or } \\
\text { poor circulation }\end{array}$ & 2 & 4 \\
\hline $\begin{array}{l}\text { History of } \\
\text { amputation or } \\
\text { ulceration or } \\
\text { neuropathic } \\
\text { fracture }\end{array}$ & 34 & 68 \\
\hline
\end{tabular}

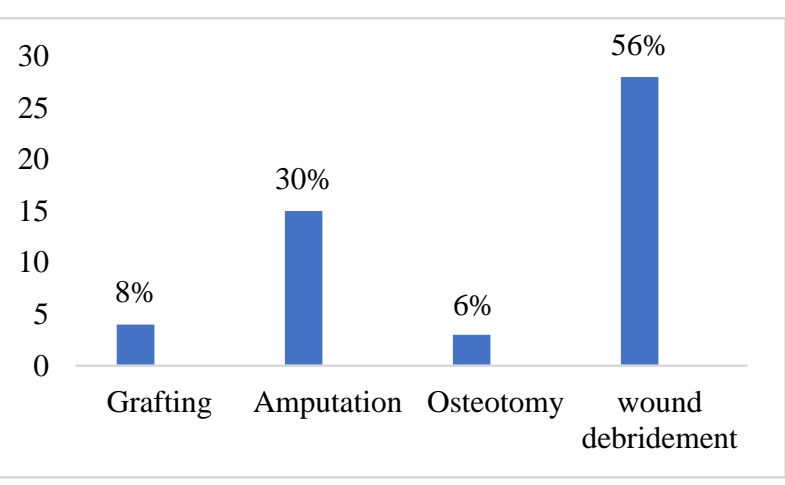

Figure 1: Surgical procedure used in DFU.

The most commonly gram-positive cocci present in the samples are methicillin-resistant Staphylococcus aureus $26 \%$ and Streptococcus pyogenes $2 \%$ (Table 7). The most commonly gram-negative bacilli present in the samples are Pseudomonas aeruginosa 10\%, Escherichia coli 6\%, Klebsiella pneumoniae 6\%, Proteus vulgaris $2 \%$ and Staphylococcus aureus 2\% (Table 7).

Table 4: Grading-classification of diabetic foot infections; Saint Elian wound score system and infectious disease society of America.

\begin{tabular}{|c|c|c|c|c|}
\hline Description & $\begin{array}{l}\text { Severity } \\
\text { grade }\end{array}$ & Score & $\begin{array}{l}\text { Number of } \\
\text { patients }\end{array}$ & $\begin{array}{l}\text { Percentage of patients } \\
(\%)\end{array}$ \\
\hline No signs or symptoms of infection & Not infected & 0 & 0 & 0 \\
\hline $\begin{array}{l}\text { Erythema between } 0.5 \mathrm{~mm}-2 \mathrm{~cm} \text {, } \\
\text { induration, tenderness, warmth and } \\
\text { purulent discharge }\end{array}$ & Mild & 1 & 8 & 16 \\
\hline $\begin{array}{l}\text { Erythema }>2 \mathrm{~cm} \text {, muscle, tendon or bone } \\
\text { or joint infection }\end{array}$ & Moderate & 2 & 36 & 72 \\
\hline $\begin{array}{l}\text { Any local infection with systemic } \\
\text { inflammatory response manifested by at } \\
\text { least } 2 \text { of following: temperature }>38 \mathrm{~F} \\
\text { or }<36 \text {, heart rate }>90 \text { beats/min, } \\
\text { respiratory rate }>20 \text { breaths/min, white } \\
\text { blood cell count }>12000 \text { cells } / \text { cu.mm }\end{array}$ & Severe & 3 & 6 & 12 \\
\hline
\end{tabular}


31 patients tested for antibiotic sensitivity. Proteus vulgaris in sample shows resistance to ampicillin, ciprofloxacin, cefazolin, co-trimoxazole and susceptibility to amikacin, gentamycin, imipenem, cefuroxime, piperacillin and tazobactam. Escherichia coli in sample mostly susceptible towards amikacin followed by gentamycin, piperacillin and tazobactam, gentamycin and resistant towards ampicillin, cefuroxime, ceftriaxone, cefazolin, ciprofloxacin and co-trimoxazole shows both resistant and susceptible.

Table 5: Distribution of antibiotics prescribed.

\begin{tabular}{|lll|}
\hline Drugs & $\begin{array}{l}\text { Number of } \\
\text { patients }\end{array}$ & $\begin{array}{l}\text { Percentage of } \\
\text { patients }(\%)\end{array}$ \\
\hline Cefotaxime & 24 & 48 \\
\hline Ceftriaxone & 1 & 2 \\
\hline Cefixime & 3 & 6 \\
\hline $\begin{array}{l}\text { Cefoperazone } \\
\text { sodium and } \\
\text { sulbactam }\end{array}$ & 1 & 2 \\
\hline Clindamycin & 2 & 4 \\
\hline Amikacin & 2 & 4 \\
\hline Gentamycin & 1 & 2 \\
\hline Amoxicillin & 1 & 2 \\
\hline $\begin{array}{l}\text { Amoxicillin and } \\
\text { clavulanic acid }\end{array}$ & 5 & 10 \\
\hline $\begin{array}{l}\text { Piperacillin and } \\
\text { tazobactam }\end{array}$ & 15 & 30 \\
\hline Ciprofloxacin & 10 & 20 \\
\hline Metronidazole & 24 & 48 \\
\hline Linezolid & 9 & 18 \\
\hline Faropenam & 2 & 45 \\
\hline
\end{tabular}

Pseudomonas aeruginosa in sample mostly susceptible towards piperacillin and tazobactam followed by imipenem, meropenem and resistant towards amikacin, ciprofloxacin, ceftazidime, tobramycin, amoxycillin, clavulanic acid and gentamycin shows both resistant and susceptible.

Table 6: Microbiological culture report.

\begin{tabular}{|lll|}
\hline Clinical details & $\begin{array}{l}\text { Number of } \\
\text { patients }\end{array}$ & $\begin{array}{l}\text { Percentage of } \\
\text { patients }(\%)\end{array}$ \\
\hline No bacteria seen & 3 & 6 \\
\hline Gram positive cocci & 14 & 28 \\
\hline $\begin{array}{l}\text { Gram negative } \\
\text { bacilli }\end{array}$ & 12 & 24 \\
\hline $\begin{array}{l}\text { Gram positive cocci } \\
\text { and gram-negative } \\
\text { bacilli }\end{array}$ & 1 & 2 \\
\hline
\end{tabular}

Klebsiella pnumoniae in sample shows mostly susceptible towards ciprofloxacin followed by nalidixic acid, amikacin and resistant to ampicillin, cefuroxime, ceftriaxone, cefazolin, co-trimoxazole and piperacillin, tazobactam, and gentamycin shows both resistant and susceptible.

Table 7: Distribution of gram-positive organisms and gram-negative organisms.

\begin{tabular}{|lll|}
\hline $\begin{array}{l}\text { Gram positive- } \\
\text { organisms and gram- } \\
\text { negative organisms }\end{array}$ & $\begin{array}{l}\text { Number } \\
\text { of patients }\end{array}$ & $\begin{array}{l}\text { Percentage } \\
\text { of patients } \\
(\%)\end{array}$ \\
\hline Streptococcus pyogenes & 1 & 2 \\
\hline MRSA & 13 & 26 \\
\hline Escherichia coli & 3 & 6 \\
\hline Staphylococcus aureus & 1 & 2 \\
\hline $\begin{array}{l}\text { Pseudomonas } \\
\text { aeruginosa }\end{array}$ & 5 & 10 \\
\hline Proteus vulgaris & 1 & 2 \\
\hline Klebsiella pneumoniae & 3 & 6 \\
\hline
\end{tabular}

Streptococcus pyogenes in sample shows resistance to erythromycin, tetracycline, oxacillin, co-trimoxazole, ciprofloxacin and susceptibility to chloramphenicol, clindamycin, gentamycin, amikacin, linezolid. MRSA in sample shows mostly both susceptible and resistant towards amikacin followed by co-trimoxazole, tetracycline, chloramphenicol, linezolid, clindamycin, ciprofloxacin, erythromycin, ceftriaxone and susceptible towards to norfloxacin, tobramycin, cefuroxime and resistant towards to oxacillin, imipenem, nalidixic acid, ofloxacin. Escherichia coli and Pseudomonas aeruginosa in sample shows resistance to ampicillin, cefuroxime, nalidixic acid, ciprofloxacin, ceftazidime, tobramycin, co-trimoxazole, cefazolin, amoxycillin, clavulanic acid and susceptibility to ceftriaxone, piperacillin and tazobactam. Staphylococcus aureus and Pseudomonas aeruginosa in sample shows resistance to erythromycin, tetracycline, amikacin, gentamycin, ciprofloxacin, ceftazidime, ceftriaxone, clindamycin, tobramycin, cotrimoxazole and susceptibility to linezolid, imipenem, chloramphenicol (Table 8). Antibiotics prescribed in both oral $42 \%$ and intravenous injection form $72 \%$ (Figure 2).

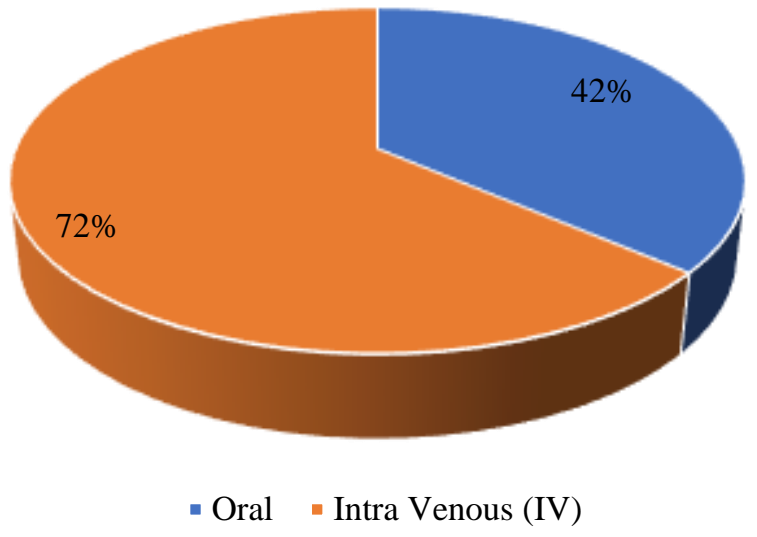

Figure 2: Route of administration of antibiotics. 
Table 8: Antibiotic sensitivity ( $n=31)$.

\begin{tabular}{|c|c|c|c|}
\hline Organisms isolated & Antibiotics & Number of susceptibility (S) & Number of resistance $(\mathbf{R})$ \\
\hline \multirow{10}{*}{ Escherichia coli } & Ampicillin & - & 2 \\
\hline & Cefuroxime & - & 2 \\
\hline & Ciprofloxacin & - & 2 \\
\hline & Ceftazidime & - & 1 \\
\hline & Co-trimoxazole & 1 & 1 \\
\hline & Cefazolin & - & 1 \\
\hline & Ceftriaxone & - & 2 \\
\hline & Piperacillin and tazobactam & 1 & - \\
\hline & Amikacin & 2 & - \\
\hline & Gentamycin & 1 & - \\
\hline \multirow{9}{*}{ Proteus vulgaris } & Ampicillin & - & 1 \\
\hline & Ciprofloxacin & - & 1 \\
\hline & Cefazoline & - & 1 \\
\hline & Co-trimoxazole & - & 1 \\
\hline & Amikacin & 1 & - \\
\hline & Gentamycin & 1 & - \\
\hline & Imipenem & 1 & - \\
\hline & Cefuroxime & 1 & - \\
\hline & Piperacillin and tazobactam & 1 & - \\
\hline \multirow{11}{*}{$\begin{array}{l}\text { Klebsiella } \\
\text { pnumoniae }\end{array}$} & Ampicillin & - & 3 \\
\hline & Gentamycin & 1 & 2 \\
\hline & Cefuroxime & - & 2 \\
\hline & Piperacillin & 2 & 1 \\
\hline & Tazobactam & - & 3 \\
\hline & Ceftriaxone & - & 3 \\
\hline & Cefazoline & - & 3 \\
\hline & Co-trimoxazole & - & 3 \\
\hline & Amikacin & 1 & - \\
\hline & Ciprofloxacin & 2 & - \\
\hline & Nalidixic acid & 1 & - \\
\hline \multirow{9}{*}{$\begin{array}{l}\text { Pseudomonas } \\
\text { aeruginosa }\end{array}$} & Amikacin & - & 3 \\
\hline & Gentamycin & 1 & 2 \\
\hline & Ciprofloxacin & - & 3 \\
\hline & Ceftazidime & - & 2 \\
\hline & Tobramycin & - & 2 \\
\hline & $\begin{array}{l}\text { Amoxycillin and clavulanic } \\
\text { acid }\end{array}$ & - & 2 \\
\hline & Meropenem & 1 & - \\
\hline & Piperacillin and tazobactam & 3 & - \\
\hline & Imipenem & 1 & - \\
\hline \multirow{12}{*}{$M R S A$} & Linezolid & 6 & 6 \\
\hline & Oxacillin & - & 11 \\
\hline & Gentamycin & 4 & 7 \\
\hline & Co-trimoxazole & 7 & 5 \\
\hline & Tetracycline & 7 & 4 \\
\hline & Clindamycin & 4 & 5 \\
\hline & Norfloxacin & 1 & - \\
\hline & Chloramphenicol & 7 & 5 \\
\hline & Ciprofloxacin & 4 & 7 \\
\hline & Amikacin & 9 & 2 \\
\hline & Erythromycin & 2 & 6 \\
\hline & Ceftriaxone & 1 & 1 \\
\hline
\end{tabular}

Continued. 


\begin{tabular}{|c|c|c|c|}
\hline Organisms isolated & Antibiotics & Number of susceptibility (S) & Number of resistance (R) \\
\hline & Imipenem & - & 1 \\
\hline & Nalidixic acid & - & 1 \\
\hline & Tobramycin & 1 & - \\
\hline & Ofloxacin & - & 1 \\
\hline & Cefuroxime & 1 & - \\
\hline \multirow{10}{*}{$\begin{array}{l}\text { Streptococcus } \\
\text { pyogenes }\end{array}$} & Erythromycin & - & 1 \\
\hline & Tetracycline & - & 1 \\
\hline & Oxacillin & - & 1 \\
\hline & Co-trimoxazole & - & 1 \\
\hline & Ciprofloxacin & - & 1 \\
\hline & Chloramphenicol & 1 & - \\
\hline & Clindamycin & 1 & - \\
\hline & Gentamycin & 1 & - \\
\hline & Amikacin & 1 & - \\
\hline & linezolid & 1 & - \\
\hline \multirow{13}{*}{$\begin{array}{l}\text { Staphylococcus } \\
\text { aureus and } \\
\text { Pseudomonas } \\
\text { aeruginosa }\end{array}$} & Erythromycin & - & 1 \\
\hline & Tetracycline & - & 1 \\
\hline & Amikacin & - & 1 \\
\hline & Gentamycin & - & 1 \\
\hline & Ciprofloxacin & - & 1 \\
\hline & Ceftazidime & - & 1 \\
\hline & Ceftriaxone & - & 1 \\
\hline & Clindamycin & - & 1 \\
\hline & Tobramycin & - & 1 \\
\hline & Co-trimoxazole & - & 1 \\
\hline & Linezolid & 1 & - \\
\hline & Imipenem & 1 & - \\
\hline & Chloramphenicol & 1 & - \\
\hline \multirow{10}{*}{$\begin{array}{l}\text { Escherichia coli } \\
\text { and Pseudomonas } \\
\text { aeruginosa }\end{array}$} & Piperacillin and tazobactam & 1 & - \\
\hline & Ceftriaxone & 1 & - \\
\hline & Ampicillin & - & 1 \\
\hline & Cefuroxime & - & 1 \\
\hline & Nalidixic acid & - & 1 \\
\hline & Ceftazidime & - & 1 \\
\hline & Tobramycin & - & 1 \\
\hline & Co-trimoxazole & - & 1 \\
\hline & Cefazolin & - & 1 \\
\hline & $\begin{array}{l}\text { Amoxicillin and clavulanic } \\
\text { acid }\end{array}$ & - & 1 \\
\hline
\end{tabular}

\section{DISCUSSION}

The first WHO global report on diabetes demonstrates that the number of adults living with diabetes has almost quadrupled since 1980 to 422 million adults. This dramatic rise is largely due to the rise in type 2 diabetes and factors driving it include overweight and obesity. In 2012 alone diabetes caused 1.5 million deaths. Its complications lead to heart attack, stroke, blindness, kidney failure and lower limb amputation. ${ }^{18}$

In our study about patient developed foot ulcer with preexisting diabetes mellitus type and it shows male patients are more than female patient with diabetic foot ulcer. And this result is similar to other study it shows male patients are more prone to get DFU. ${ }^{19}$ Age group of 50 to 60 patients had higher prevalence of DFU this result was similar in other study. ${ }^{20}$ Based on the international diabetic federation (IDF) patient history are classified as risk categories. ${ }^{21}$

In our study according to Saint Elian wound score system and infectious disease society of America patients are mostly falls under grade 2 but in another study, patients are mostly in grade $1 .^{22}$ The most commonly prescribed antibiotics in DFU are cefotaxime $48 \%$ and metronidazole $48 \%$ and also another study shows similar class of antibiotics are prescribed such as cephalosporins $21.4 \%$ and nitroimidazole 26.1 in total of 35 diabetic foot ulcer patients. ${ }^{19}$ 
The most common organism present in the isolated samples are classified as gram-positive organisms $28 \%$ and gram-negative organisms $24 \%$ where in another study gram-negative organisms $73.1 \%$ are more than the gram-positive organisms $26.8 \%$ present in total of 41 patients. ${ }^{19}$

Both gram-negative organism and gram-positive organism present in the sample $2 \%$ is less when compared to another study that had both gram- negative organism and gram-positive organisms $57.5 \%$ of 46 patients. $^{23}$

The gram-negative organisms are Escherichia coli (6\%), Staphylococcus aureus (2\%), Pseudomonas aeruginosa (10\%), Proteus vulgaris (2\%), Klebsiella pneumoniae (6\%) where in another study Proteus species (12.6), E. Coli (12.0\%), Pseudomonas aeruginosa (9.8\%), Klebsiella species $(6.6 \%){ }^{23}$ The gram-positive organisms are Streptococcus pyogenes (2\%) and MRSA (26\%) where in another study MRSA is more $(47.8 \%)$ of 59 infected patients. ${ }^{24}$

MRSA is present in the most of the patient pus samples and it is difficult to treat because most of the antibiotics are resistance towards MRSA. MRSA strains play a significant role as an important pathogen in diabetic foot infection (DFI) and have become a public health concern due to their increased virulence and resistance to an increasingly broad spectrum of antibiotics. ${ }^{25}$

\section{CONCLUSION}

In our study shows that most of the prescribed antibiotics for DFU are cephalosporin and macrolide class of antibiotics. And also observed only moderate level culture sensitivity test are done. MRSA organism is mostly isolated in samples.

Lack of antibiotic sensitivity test leads to growth of organism, wrong antibiotic selection and irrational use of antibiotics. And also observed patient developed resistance to linezolid antibiotic when physician used as a first choice of drug to treat diabetic foot infection including methicillin-resistant Staphylococcus aureus (MRSA) infected patients. So, our study may help to considering antibiotics which shows susceptible to organisms.

Funding: No funding sources

Conflict of interest: None declared

Ethical approval: The study was approved by the Institutional Ethics Committee

\section{REFERENCES}

1. Zafar A. Management of diabetic foot: two years' experience. J Ayub Med Coll. 2001;13(1):14-6.

2. Mahmood K, Akhtar TS, Talib A, Abbasi B, Salekeen SU, Naqvi IH. Clinical profile and management outcome of Diabetic Foot Ulcers in a Tertiary care Hospital. J College Physicians Surg Pakistan. 2008;18(7):408-12.

3. Armstrong, David G, Andrew JM, Boulton B, Sicco A. Diabetic Foot Ulcers and their Recurrence. New Engl J of Med. 2017;376:2367-75.

4. Everett E, Mathiodakis N. Update on management of diabetic foot ulcers. Ann NY Acad Sci. 2018; 1411(1):153-65.

5. Mathangi T, Prabhakaran P. Prevalence of Bacteria Isolated from Type 2 Diabetic Foot Ulcers and the Antibiotic Susceptibility Pattern. Int J Curr Microbiol App Sci. 2013;2(10).

6. Singh N, Armstrong DG, Lipsky BA. Preventing foot ulcers in patients with diabetes. JAMA. 2005;293(2): 217-28.

7. Marzoq, Shiaa, Zaboon, Baghlancy, Alabbood. Assessment of the outcome of Diabetic Foot Ulcers in Basrah, Southern Iraq: A Cohort Study. Int J Diabetes Metab. 2019;25:33-8.

8. Alex R, Ratnaraj B, Winston B. Risk factors for Foot Ulcers in patients with Diabetes mellitus: A Short Report from Vellore, South India. Indian J Community Med. 2010;35(1):183-5.

9. Balin OS, Tartar SA, Ugur K. Pentraxin-3: A new parameter in predicting the severity of diabetic foot infection. Int Wound J. 2019.

10. Williams DT, Hilton JR, Harding KG. Diagnosing foot infections in diabetes. Clin Infect Dis. 2004;39(2):583-6.

11. Lipsky BA, Berendt AR, Cornia PB. Infectious Diseases Society of America Clinical practice guidelines for the diagnosis and treatment of diabetic foot infections. Clin Infect Dis. 2010:54(12):132-73.

12. Cunha BA. Antibiotic selection for diabetic foot infections: a review. Journal Foot Ankle Surg. 2000;39(4).

13. Abbas M, Uckay I, Lipsky BA. In diabetic foot infections antibiotics are to treat infection, not to heal wounds. Expert Opin Pharmacother. 2015;16:821-32.

14. Desai SV. Rational use of antibiotics in clinical practice: Pharmacological considerations. J Integr Health Sci. 2019;7:1-2.

15. Brian L. Storm, Pharmacoepidemiology, chapter 1, 6th edition. Available at https://doi.org/10.1002/ 9781119413431.ch1. Accessed on 18 October 2019.

16. Promoting rational use of medicines: core components, WHO Policy Perspectives on medicines, September 2002. Essential medicines and Health Products Information Portal, a World Health Organization Resource. Available at https://www. who.int/medicines/areas/rational_use/en. Accessed on 3 January 2020.

17. Jain S, Upadhyaya P, Goyal J, Kumar A, Jain P, Seth $\mathrm{V}$, et al. A systematic review of prescription pattern monitoring studies and their effectiveness in promoting rational use of medicines. Perspect Clin Res. 2015;6(2):86-90.

18. Global report on diabetes, World Health Organisation. Available at https://www.who.int/ 
diabetes/global-report/en. Accessed on 3 January 2020.

19. Pillai AV. A study on prevalence and Prescription Pattern of Diabetic Foot Ulcer. Int J Sci Health Care Res. 2019;4(2).

20. Zachariah. Study on drug utilization, prescribing pattern and use of antibiotics in the management of Diabetic Foot Ulcer. IJIPSR. 2015;3(8):1037-49.

21. International Diabetes Federation (IDF) Clinical Practice Recommendations on the Diabetic Foot2017, a guide for health professionals. Available at http://www.idf.org. Accessed on 3 January 2020.

22. Jesus MDFR, Medina GMF, Mendiola MFN. Saint Elian Wound scoring system for the follow-up of diabetic foot ulcers and its therapeutic relevance. Rev Latinoam Cir. 2012;2(1):14-20.

23. Gadepalli R, Dhawan B, Sreenivas V, Kapil A, Ammini AC, Chaudhry R. A Clinico-microbiological Study of Diabetic Foot Ulcers in an Indian Tertiary Care Hospital. Diabetes Care. 2006;29(8)
24. Tentolouris N, Petrikkos G, Vallianou N, Zachos C, Daikos GL, Tsapogas P, et al. Prevalence of methicillin-resistant Staphylococcus aureus in infected and uninfected diabetic foot ulcers. European Society Clin Microbiology Infectious Diseases. 2006;12(2):186-9.

25. Feng SH, Chu YJ, Wang PH, Jun X, Min D, Li XM. Risk factors and gene type for infections of MRSA in diabetic foot patients in Tianjin, China. Int J Low Extrem Wounds. 2013;12(2):106-12.

Cite this article as: Paramasivamsasanger $\mathrm{K}$, Mariappan P, Govindasamy D, Karunakaran P, Ramesh R. A prospective observational study of drug prescription pattern of antibiotics in diabetic foot ulcer in tertiary care teaching hospital. Int $\mathrm{J}$ Basic Clin Pharmacol 2020;9:1020-7. 